\title{
Determination of rock elastic parameters using VP/VS relation- ship for escravos area, Niger delta, Nigeria
}

\author{
J. T. Ajayi *, A. A. Adepelumi, C. Agih \\ Department of Geology, Obafemi Awolowo University, Ile-Ife, Nigeria \\ *Corresponding author E-mail: tobaretoo@gmail.com
}

\begin{abstract}
The elastic properties of sedimentary rocks in the Escravos area, Niger delta, Nigeria, have been computed for six boreholes drilled to a maximum of $22 \mathrm{~m}$. Compressional wave (Vp), Shear wave (Vs) velocities and density ( $\rho$ ) values were computed for the lithologies at the six different boreholes. The elastic properties were estimated using the computed Vp, Vs and $\rho$ values. Empirical relations between the derived elastic and physical properties of the subsurface lithologies encountered in the boreholes were established. The results show three distinctive layers comprising Sand, Sandy clay and Clayey sand existing in the boreholes. The computed values of the elastic properties show that the formation encountered in the wells are moderately dense and saturated with water. A distinct linear relationship existing between Vp / Vs was observed; while an exponential relationship was derived for $\sigma / \mathrm{Vs}$. Empirical relationships derived from this study for Vp - Vs is given as Vs $=0.902 \mathrm{Vp}-1164$, and for Vs - Poisson's is given as $\sigma=-1 \mathrm{E}-07 \mathrm{Vs}^{2}-4 \mathrm{E}-05 \mathrm{Vs}+0.502$. The values of allowable bearing capacity and the settlement suggest that the study area is able to support engineering construction. Empirical relations established for Vp - Vs and Vs - Poisson's is characteristics of sedimentary terrain, and can be used within the Escravos area, Niger Delta, Nigeria.
\end{abstract}

Keywords: Allowable Bearing Capacity, Elastic Properties, Empirical Relations, Settlement.

\section{Introduction}

For any engineering and geotechnical project, rock elastic constants provide valuable information about the subsurface rock. The involvement of geophysics in civil and environmental engineering has become a promising approach. The deformational characteristics of rocks are essential in the design and construction of any structure on the rock. The seismic method utilizes the propagation of waves through the earth. Wave propagation depends upon the elastic properties of rocks (Sheriff 1989). A body subjected to stress undergoes a change in shape and/or size known as strain Elasticity of a body is defined by its ability to resist deformation and the tendency to restore itself back to its original shape and/or size when the stress applied is removed.

A Perfectly elastic body is one that recovers completely after being deformed. Many substances including rocks are considered to be perfectly elastic provided that the deformations are small as in a seismic survey.

The Hooke's law explains the concept of stress and strain. The borehole seismic method has been proven a useful tool for the delineation of seismic wave propagation properties near a well (Hardage 1985). Compressional wave and Shear wave velocities and densities have been acquired in six different wells from which the elastic properties have been obtained and the subsurface lithologies predicted; empirical relations were also established for the survey area, Niger Delta. It has been discovered that the determination of seismic velocities, elasticity modulus and structural properties of soils is not enough in the design of engineering projects. In design of engineering structures, one of the main factors related to soil is bearing capacity and other is settlement so that is subgrade reaction (Keceli 2012). Many investigators have extensively studied to obtain the relations between the various parameters of soil mechanics and seismic wave velocities. (Some of them are Hardin \& Black 1968 and Ohkubo \& Terasaki 1976). Few authors have published an empirical formula between seismic wave velocities and Standard Penetration Test (SPT) N- blow counts for the determination of bearing capacity, (Imai \& Yoshimura 1972, Imai 1975, Parry 1977, Sternberg et al. 1990). Keçeli $(1990,2000)$ showed that the determination of the presumptive or allowable bearing capacity could be obtained by means of the Seismic Method.

\section{Location and geology of the study area}

Escravos is located in the Niger Delta about 100 kilometers (62 mi) southeast of Lagos. It is located precisely in Delta State, Nigeria at coordinates $5^{\circ} 36^{\prime} 57^{\prime} ' \mathrm{~N}$ and $5^{0} 12^{\prime} 20^{\prime} ' \mathrm{E}$ (Fig. 1). The Niger Delta is the youngest sedimentary basin within the Benue Trough system. The Niger delta development began after the Eocene tectonic phase. Up to $12.0 \mathrm{~km}$ of deltaic and shallow marine sediments have been accumulated in the basin. The Niger and Benue Rivers is the main supplier of sediments. Three lithostratigraphic units are distinguished in the Tertiary Niger Delta.

The basal Akata Formation which is predominantly marine prodelta shale is overlain by the paralic sand/shale sequence of the Agbada Formation. The topmost section is the continental upper deltaic plain sands - the Benin Formation. Virtually all the hydrocarbon accumulations in the Niger Delta occur in the sands and sandstones of Agbada Formation where they are trapped by rollo- 
ver anticlines related to growth fault Development (Ekweozor \& Daukoru 1994, Michele et al. 1999, Uko 1996).

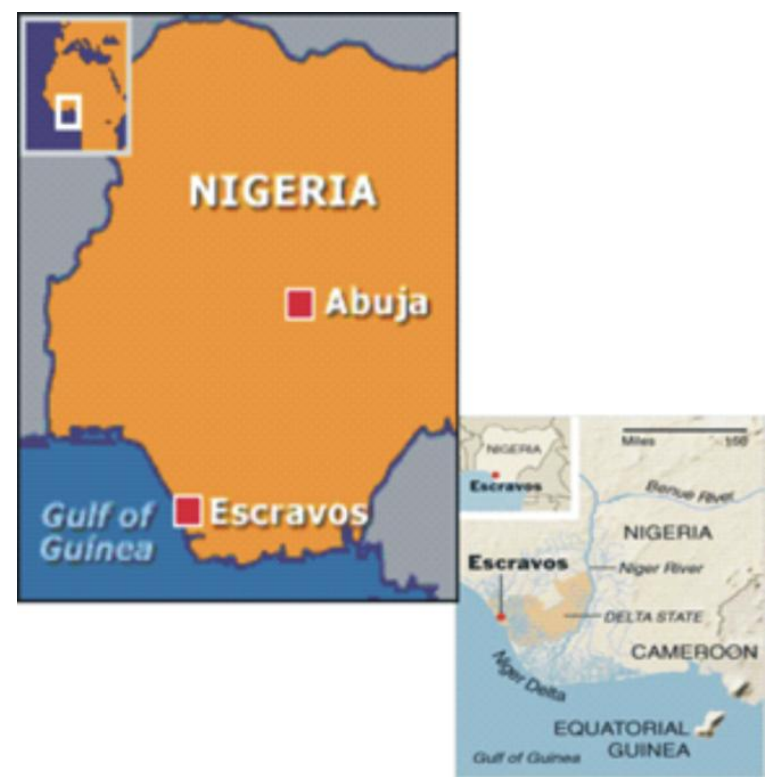

Fig. 1: The Point Location of Escravos on the Map of Nigeria.

\section{Materials and methods}

The basic data used for this work comprise a set of data from six wells from a Field drilled in the Niger Delta region precisely in Escravos. The data was acquired using borehole seismic method. Borehole seismic technique in geophysical exploration, involves measuring the in situ behavior of downgoing and upgoing seismic wavefields which propagate through a stratigraphic sequence near the well (Fig. 2).

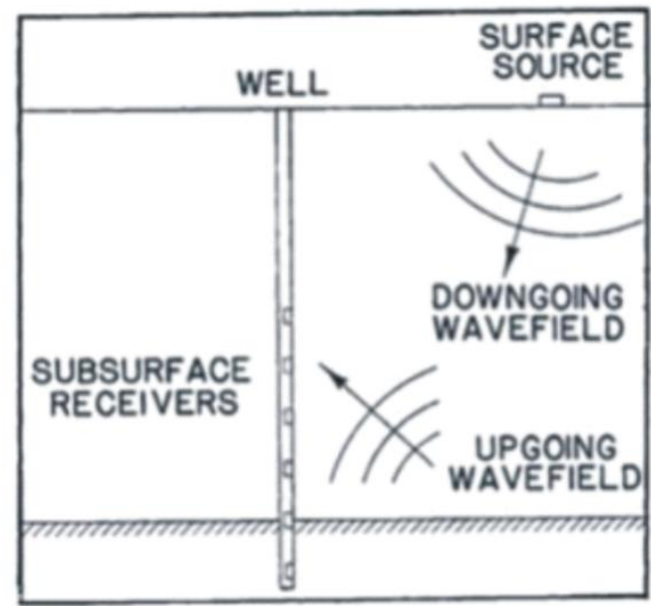

Fig. 2: Arrangement of Source - Receiver Geometry Used To Record Borehole Seismic Data (Hardage 1989).

Various engineering parameters were calculated and used in interpretation: Young's Modulus (E), Shear Modulus (G), Bulk Modulus (K), Safety Factor (Fs), Bearing Capacity (Q) and Settlement (dz).

The universal relations among $\mathrm{K}, \sigma$ and $\mathrm{G}$ and among $\mathrm{E}, \sigma$ and $\mathrm{G}$ are given in the equations respectively (Dobrin \& Savit 1988)

$$
\begin{aligned}
& K=2 G \frac{1+\sigma}{3(1-2 \sigma)} \\
& E=2 G[1+\sigma]
\end{aligned}
$$

If the Poisson's ratio is written with an equivalent based on $\mathrm{Vp} / \mathrm{Vs}$ ratio
$\sigma=\frac{(\mathrm{Vp} / \mathrm{Vs})^{2}-2}{2(\mathrm{Vp} / \mathrm{Vs})^{2}-2}$

Additionally, the existing relation between $\mathrm{G}$ and $\mathrm{Vs}$ is given in the Eqn. (4)

$\mathrm{G}=\rho \mathrm{Vs}^{2} ; \rho=$ density of soil

The values of $\mathrm{Vp} / \mathrm{Vs}$ and Fs depend on properties of soils and rocks increase from loose soil to hard rock. When Fs and $\mathrm{Vp} / \mathrm{Vs}$ are used together in soil studies, better reliable the results may be achieved than when only one of $\mathrm{Fs}$ or $\mathrm{Vp} / \mathrm{Vs}$ is used. Studies have shown that $\mathrm{Vp} / \mathrm{Vs}$ is approximately twice of Fs.

Fs $\approx \frac{V p}{V s} \quad$ Fs $\leftrightarrow \frac{V p}{V s}$

For pre-consolidated soils, elastic settlement is predominant. Hook's Law defines the elasticity modulus, E, as

$\mathrm{E}=\frac{\text { longitudinal stress }}{\text { longitudinal strain }}$

$E$ is also defined in terms of seismic velocities as

$\mathrm{E}=\rho \mathrm{Vs} \frac{3 \mathrm{Vp} \mathrm{p}^{2}-4 \mathrm{Vs}^{2}}{\mathrm{Vp}^{2}-\mathrm{Vs}^{2}}$

Hook's law may be expressed for the settlement of the soil medium with $\mathrm{z}$ depth in a vertical direction as follows:

$\mathrm{d}_{\mathrm{Z}}=\mathrm{dZ}=\frac{\text { Qult }}{\mathrm{E}} \mathrm{Z}$

Where:

$\mathrm{Q}_{\mathrm{ult}}=$ load per unit area is the stress value depending on the depth, $\mathrm{Z}$

$\mathrm{d}=$ settlement for unit value

$\mathrm{d}_{\mathrm{Z}}=$ settlement value for the soil column with depth $\mathrm{z}$

$\mathrm{Z}=$ active depth which is obtained

$\mathrm{dZ}=$ total elastic settlement for the active depth $\mathrm{z}$

The set of equations $1-8$ were used in estimating the various elastic parameters and the engineering properties.

The data obtained from the seismograph (seismogram) were processed using Pickwin.

Software to obtain the arrival time for P-wave and S-wave. With the geophone separations of $5 \mathrm{~m}$ interval, $\mathrm{T}$-X graph were plotted for the different locations using Plotrefa software and the inverse of the slope were obtained as velocity for each of the layer penetrated. The Pick-win software helped in picking the arrival times while the Plotrefa software directly converted the slope into Velocity for the different layers and geologic models where generated.

\section{Results and discussion}

The computed elastic parameters of the sedimentary rocks in the Escravos area of Niger Delta are given in Table 1. The lithologies encountered are Sand, Sand clay and clayey sand. The depths of investigation vary from one well to the other. Generally, the Pwave and S-wave velocities obtained for the six wells range from $1498.4 \mathrm{~m} / \mathrm{s}$ to $1669.8 \mathrm{~m} / \mathrm{s}$ and from $187.8 \mathrm{~m} / \mathrm{s}$ to $342.2 \mathrm{~m} / \mathrm{s} \mathrm{respec-}$ tively. The bulk moduli ranges between $3.779 \mathrm{GPa}$ and $4.773 \mathrm{GPa}$ while the density of the formation encountered in the wells varies from $1719.2 \mathrm{~kg} / \mathrm{cm}^{3}$ to $1824.8 \mathrm{~kg} / \mathrm{cm}^{3}$. The observed settlement varies from $0.083 \mathrm{~m}$ to $3.068 \mathrm{~m}$ with an increase in settlement with depth.

The Young's modulus which is a measure of the property of the rock to resist deformation ranges from $0.181 \mathrm{GPa}$ to $0.628 \mathrm{GPa}$; the Young's moduli confirm the three lithologic layers encountered in the boreholes. The Poisson's ratios for the various wells vary between 0.478 and 0.492 , which is high. The Safety Factor (i.e. $\mathrm{Vp} / \mathrm{Vs}$ ) ranges from $4.880-7.722$. The shear moduli vary from $0.061 \mathrm{GPa}$ to $0.212 \mathrm{GPa}$. The results confirm that the lithology in the area is sandy and contains some clay. The delineated porosity ranges from $26 \%$ to $28 \%$. The allowable bearing capacity varies between $0.404 \mathrm{~kg} / \mathrm{cm}^{2}$ and $1.272 \mathrm{~kg} / \mathrm{cm}^{2}$. The computed values of the elastic properties show that the formation encountered in the wells are moderately dense and saturated with water. 


\subsection{Geologic models}

The geologic models representing the subsurface lithologies were produced. Time-term inversion and tomographic inversion techniques were carried out to produce the models. The configuration used for the geologic models is as follows: receiver interval- 4, no of receivers- 21 , no of sources- 4 , no of layers- 3 or 2 as the timedistance curves specify. The geologic models show the topography of the subsurface and the number of layers. The depth was also shown in the geologic models representing the subsurface formations from each set.

\subsubsection{P-wave geologic model of well 1}

The P-wave geologic model generated for Well 1 (see Fig. 3) show that three distinct lithologies characterize the Well 1 viz: Sand, Sandy clay and Clayey sand. The P-wave velocity in the sand ranges from $1498.4 \mathrm{~m} / \mathrm{s}$ to $1531.9 \mathrm{~m} / \mathrm{s}$ and that of S-wave ranges $187.8 \mathrm{~m} / \mathrm{s}$ to $191.8 \mathrm{~m} / \mathrm{s}$. The sandy clay layer is characterized by an average velocity of $1500 \mathrm{~m} / \mathrm{s}$. The model shows the number of layers and the thicknesses of the individual layers. Layer 1 has maximum thickness of $5.4 \mathrm{~m}$, layer 2 has a maximum thickness of $11.5 \mathrm{~m}$, layer 3 has a maximum thickness of $16.9 \mathrm{~m}$ and the total depth extent is about $26.0 \mathrm{~m}$ (Fig. 3).

\subsubsection{P-wave geologic model of well 2}

From Fig. 4, the geologic model shows that three distinct layers characterize Well 2 viz: Sand, Sandy clay and clayey sand. The Pwave velocity in the sand ranges from $1546.0 \mathrm{~m} / \mathrm{s}$ to $1595.8 \mathrm{~m} / \mathrm{s}$ and that of S-wave ranges $230.6 \mathrm{~m} / \mathrm{s}$ to $275.5 \mathrm{~m} / \mathrm{s}$. The sandy clay layer is characterized by an average velocity of $1580 \mathrm{~m} / \mathrm{s}$. The model shows the number of layers and the thicknesses of the individual layers. Layer 1 has maximum thickness of $9.2 \mathrm{~m}$, layer 2 has a maximum thickness of $12.3 \mathrm{~m}$, layer 3 has a maximum thickness of $15.3 \mathrm{~m}$ and the total depth extent is about $32.0 \mathrm{~m}$.

\subsubsection{P-wave geologic model of well 3}

From Fig. 5, the geologic model shows that three distinct layers characterize Well 3 viz: Sand, Sandy clay and Clayey sand. The Pwave velocity in the sand ranges from $1567.8 \mathrm{~m} / \mathrm{s}$ to $1669.8 \mathrm{~m} / \mathrm{s}$ and that of S-wave ranges $250.3 \mathrm{~m} / \mathrm{s}$ to $342.2 \mathrm{~m} / \mathrm{s}$. The model shows the number of layers and the thicknesses of the individual layers. Layer 1 has maximum thickness of $6.2 \mathrm{~m}$, layer 2 has a maximum thickness of $8.5 \mathrm{~m}$, layer 3 has a maximum thickness of $20.8 \mathrm{~m}$ and the total depth extent is about $32.0 \mathrm{~m}$.

\subsubsection{P-wave geologic model of well 4}

From Fig. 6, the geologic model shows that three distinct layers characterize Well 4 viz: Sand, Sandy clay and Clayey sand. The Pwave velocity in the sand ranges from $1506.6 \mathrm{~m} / \mathrm{s}$ to $1569.3 \mathrm{~m} / \mathrm{s}$ and that of S-wave ranges $195.1 \mathrm{~m} / \mathrm{s}$ to $251.7 \mathrm{~m} / \mathrm{s}$. The model shows the number of layers and the thicknesses of the individual layers. Layer 1 has maximum thickness of $8.5 \mathrm{~m}$, layer 2 has a maximum thickness of $20.8 \mathrm{~m}$, layer 3 has a maximum thickness of $16.2 \mathrm{~m}$ and the total depth extent is about $35.5 \mathrm{~m}$.

\subsubsection{P-wave geologic model of well 5}

From Fig. 7, the geologic model shows that two distinct layers characterize Well 5 viz: Sand, Sandy clay and Sand. The P-wave velocity in the sand ranges from $1528.9 \mathrm{~m} / \mathrm{s}$ to $1545.4 \mathrm{~m} / \mathrm{s}$ and that of $\mathrm{S}$-wave ranges $214.6 \mathrm{~m} / \mathrm{s}$ to $229.4 \mathrm{~m} / \mathrm{s}$. The model shows the number of layers and the thicknesses of the individual layers. In well 5, 2 layers were penetrated. Layer 1 has maximum thickness of $6.9 \mathrm{~m}$ layer 2 has a maximum thickness of $14.6 \mathrm{~m}$ and the total depth extent is about $21.6 \mathrm{~m}$.

Table 1: Summary of Layer Parameters and the Elastic Properties of Escravos Area, Niger Delta.

\begin{tabular}{lllllllllllll}
\hline \multirow{2}{*}{ Well } & Depth $(\mathrm{m})$ & $\begin{array}{l}\text { Avg } \\
\text { Vp }(\mathrm{m} / \mathrm{s})\end{array}$ & $\begin{array}{l}\text { Avg } \\
\text { Vs }(\mathrm{m} / \mathrm{s})\end{array}$ & $\begin{array}{l}\text { Avg } \\
\text { Density }\left(\mathrm{kg} / \mathrm{m}^{3}\right)\end{array}$ & $\begin{array}{l}\text { Avg } \\
\text { Vp/Vs }\end{array}$ & $\begin{array}{l}\text { Avg } \\
\sigma\end{array}$ & $\begin{array}{l}\text { Avg } \\
\Phi\end{array}$ & $\begin{array}{l}\text { Avg } \\
\text { G }(\mathrm{Gpa})\end{array}$ & $\begin{array}{l}\text { Avg } \\
(\mathrm{Gpa})\end{array}$ & $\begin{array}{l}\text { Avg } \\
\mathrm{K} \\
(\mathrm{Gpa})\end{array}$ & $\begin{array}{l}\text { Avg } \\
\text { Qa } \\
\left(\mathrm{kg} / \mathrm{cm}^{2}\right)\end{array}$ & $\begin{array}{l}\text { Avg } \\
\mathrm{dZ}(\mathrm{cm})\end{array}$ \\
\hline 1 & 16 & 1507.3 & 195.8 & 1800 & 7.7 & 0.49 & 0.279 & 0.067 & 0.201 & 3.89 & 0.446 \\
2 & 18 & 1576.4 & 258.0 & 1811 & 6.12 & 0.48 & 0.271 & 0.121 & 0.359 & 4.34 & 0.767 \\
3 & 16 & 1617.5 & 295.1 & 1767 & 5.51 & 0.48 & 0.267 & 0.155 & 0.460 & 4.42 & 0.956 \\
4 & 22 & 1542.5 & 227.5 & 1801 & 6.81 & 0.49 & 0.275 & 0.094 & 0.279 & 4.16 & 0.606 \\
5 & 7 & 1535.0 & 220.2 & 1799 & 6.98 & 0.49 & 0.276 & 0.087 & 0.260 & 4.12 & 0.569 \\
6 & 22 & 1601.8 & 280.9 & 1820 & 5.71 & 0.48 & 0.269 & 0.144 & 0.427 & 4.48 & 0.897 \\
\hline
\end{tabular}

NOTE: Avg- Average, Vp- Primary Wave Velocity, Vs- Secondary Wave Velocity, $\sigma$ - Poisson’s ratio, $\Phi$ - Porosity, G- Shear Modulus, E- Young's Modulus, K- Bulk Modulus, Qa- Allowable Bearing Capacity (Ultimate Bearing Capacity/ Safety Factor), dZ- Settlement

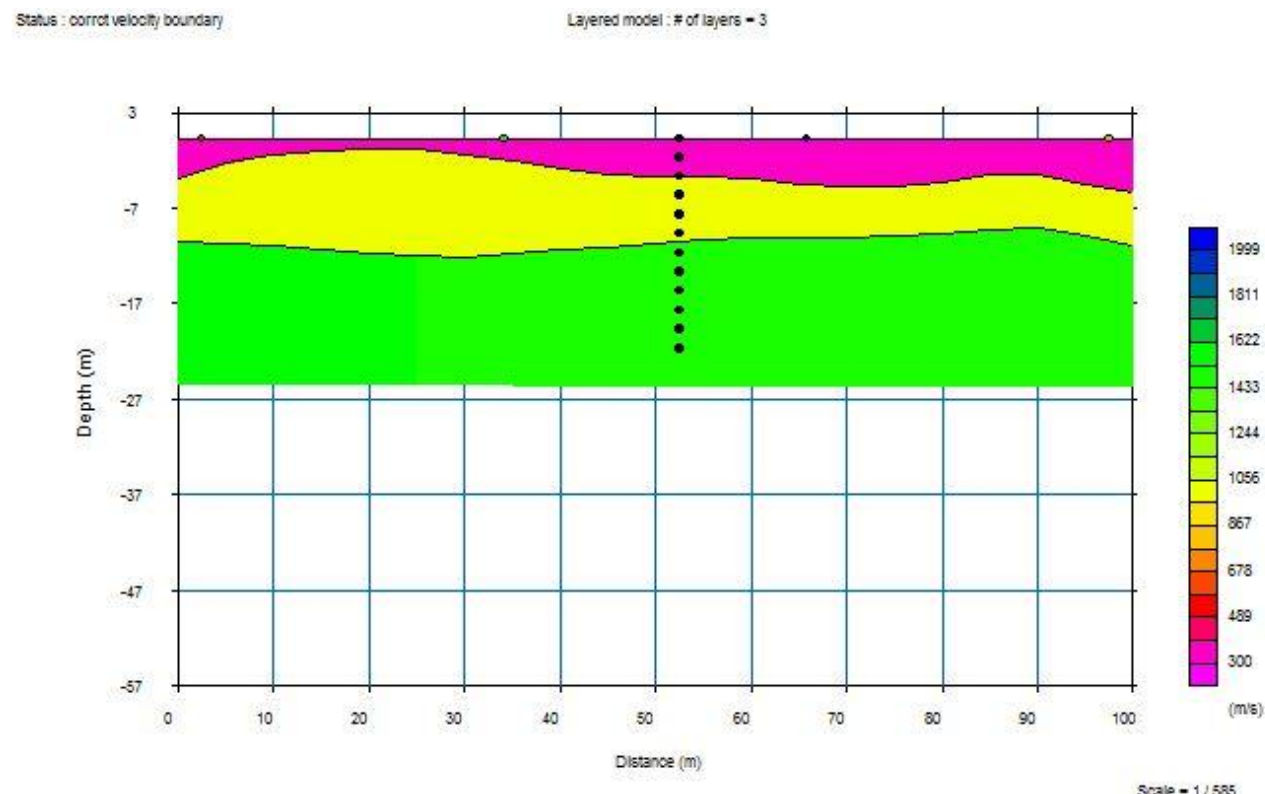

Fig. 3: Geologic Model of Well 1. 


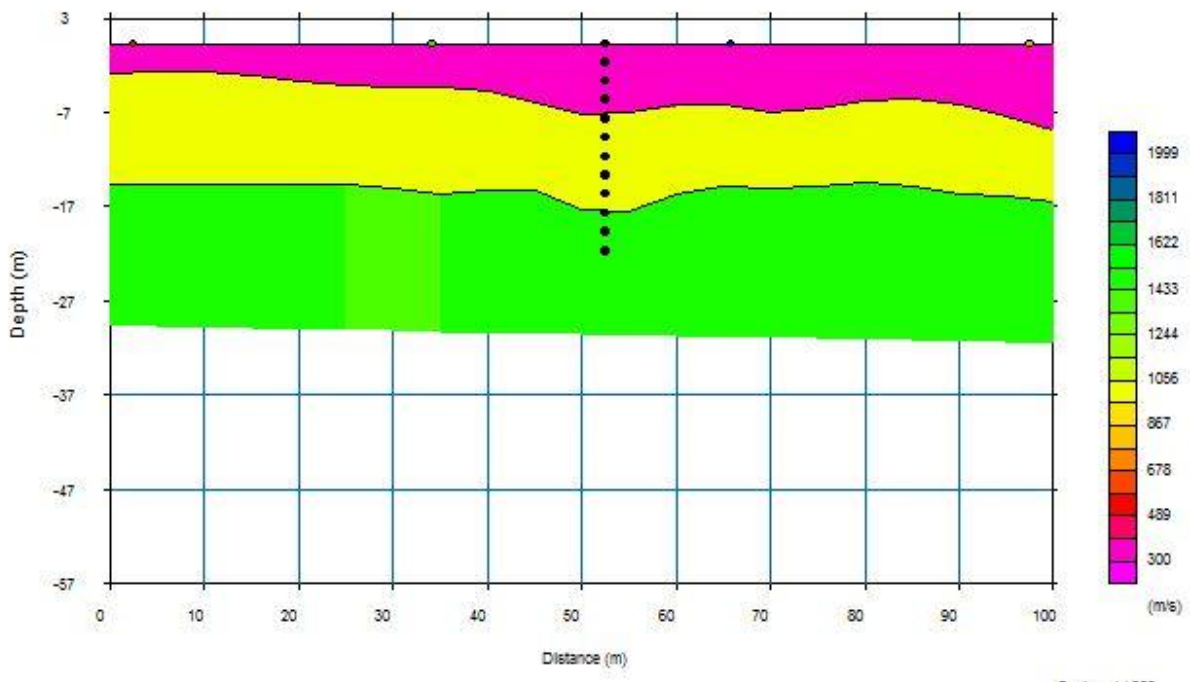

Fig. 4: Geologic Model of Well 2.

Stans : corret veloonj boundary

Lajeres mosel : \# of lajers - 3

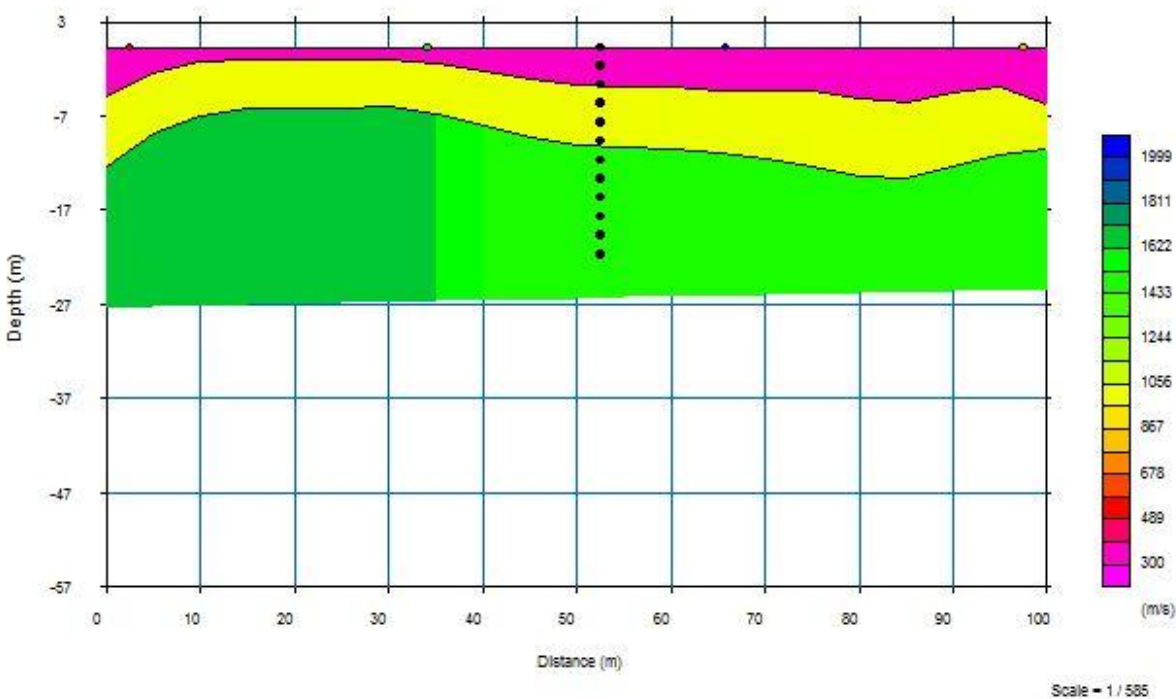

Fig. 5: Geologic Model of Well 3.

Stasus : corrch veloochy boundary

Lajered model : \# of lajers - 3

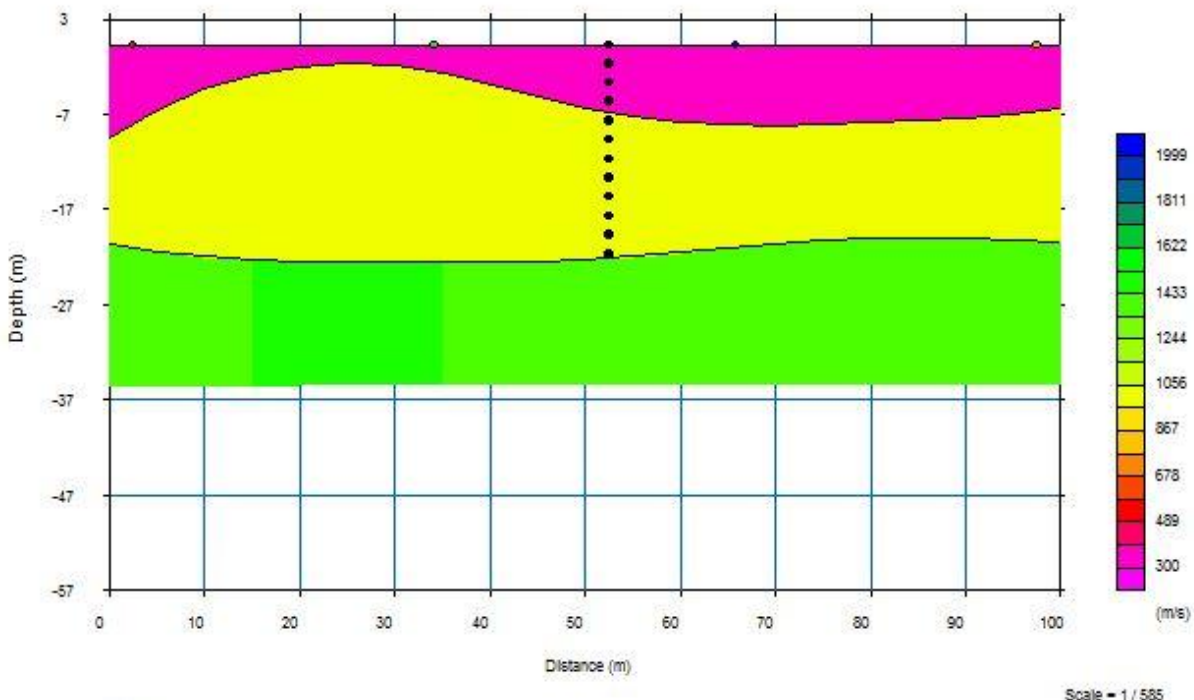

Fig. 6: Geologic Model of Well 4. 


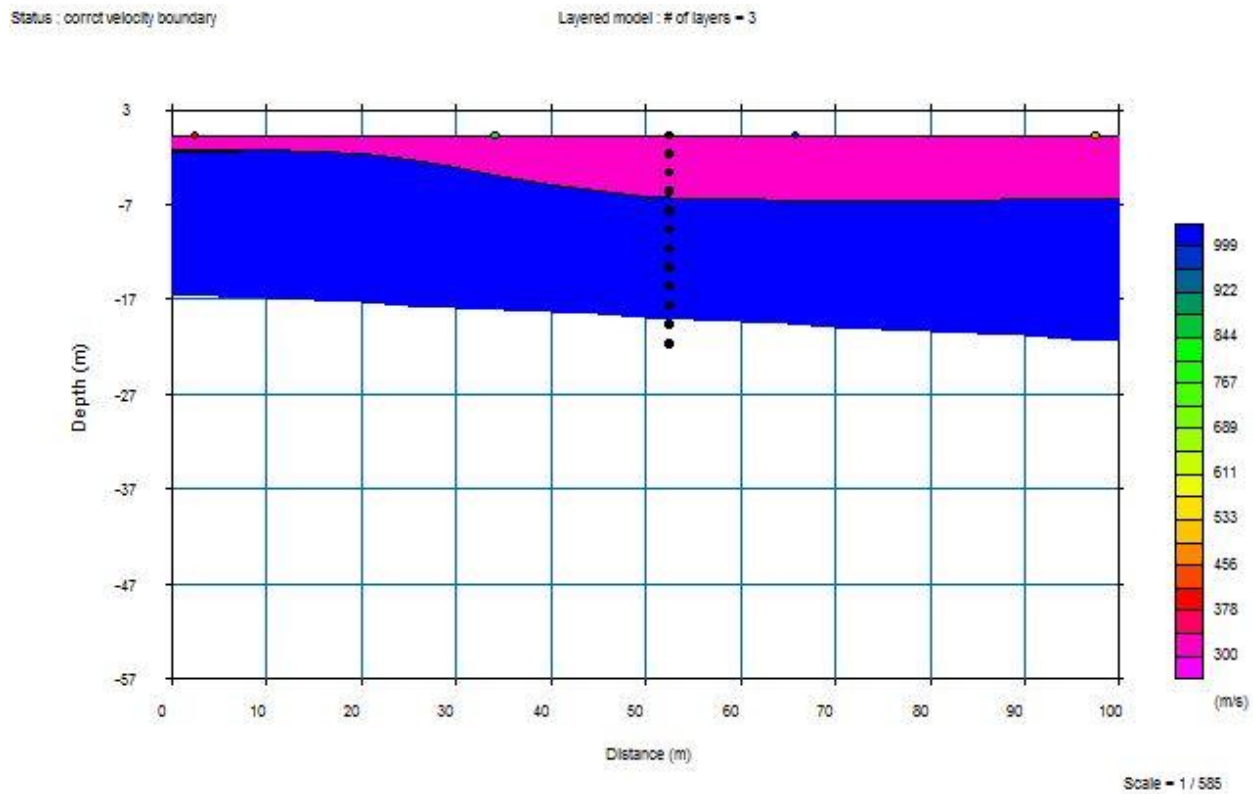

Fig. 7: Geologic Model of Well 5.

\subsubsection{P-wave geologic model of well 6}

From Fig. 8, the geologic model shows that three distinct layers characterize Well 6 viz: Sand, Sandy clay and clayey sand. The Pwave velocity in the sand ranges from $1528.9 \mathrm{~m} / \mathrm{s}$ to $1545.4 \mathrm{~m} / \mathrm{s}$ and that of S-wave ranges $214.6 \mathrm{~m} / \mathrm{s}$ to $229.4 \mathrm{~m} / \mathrm{s}$. The model shows the number of layers and the thicknesses of the individual layers. In well 6, 3 layers were penetrated. Layer 1 has maximum thickness of $3.8 \mathrm{~m}$, layer 2 has a maximum thickness of $7.1 \mathrm{~m}$, layer 3 has a maximum thickness of $14.5 \mathrm{~m}$ and the total depth extent is about $27 \mathrm{~m}$.

\subsection{S-wave velocity models}

Using WaveEq module, S-wave velocity models showing the Swave velocity variation with depth within the subsurface geology penetrated by the well was produced. Using the dispersion curves that were generated and an initial model was generated by the program after which iteration was carried out. For each of the models, iteration curves were plotted, some of which converge at zero. This approves the accuracy of the S-wave velocity models. With careful observation of the S-wave velocity models, it is observed that at some depths in each of the wells, there appear to be a decrease in both $\mathrm{P}$-wave and $\mathrm{S}$-wave velocities, due to the presence of little clay materials within the sand unit. At these particular depths, it is observed that there is also a decrease in shear modulus. At these depths also, there is a reduction in bearing capacity and subsequently ultimate bearing capacity.

The $\mathrm{S}$-wave velocity models show that the unit change in velocity at some specific intervals. In generating all the $S$-wave velocity models, inversion was carried out using Least Square Smoothening Method. The Root Mean Square (RMS) error in percentage was plotted against the number of iterations. The iteration curve converges to zero (Figs. 9 to 20).

\subsubsection{S-wave velocity model and iteration curve of well 1}

The S-wave velocity model obtained shows secondary wave velocity variation with depth (Fig. 9). Up to about $3.0 \mathrm{~m}$, the velocity increases gradually and then it begins to reduce to about $7.9 \mathrm{~m}$ at which depth the S-wave velocity increases again. The decrease in S-wave velocity between $3.0 \mathrm{~m}$ and $7.9 \mathrm{~m}$ is due to the presence of little clay materials within the sand unit. At these depths also, there is a decrease in shear modulus. At these depths also, there is a reduction in bearing capacity and subsequently, ultimate bearing capacity.

\subsubsection{S-wave velocity model and iteration curve of well 2}

The $S$-wave velocity model shows secondary waves velocity variation with depth (Fig. 11). Up to about $4.5 \mathrm{~m}$, peaks at $5.0 \mathrm{~m}$, the velocity increases gradually and then it begins to decrease to about $10.4 \mathrm{~m}$ from which the S-wave velocity increases again and decreases at $11.9 \mathrm{~m}$. The decrease in S-wave velocity between $5.0 \mathrm{~m}$ and $10.4 \mathrm{~m}$ is due to the presence of clay within the sand unit. At these particular depths, it is observed that there is a corresponding decrease in shear modulus. At these depths also, there is a decrease in bearing capacity and subsequently, ultimate bearing capacity.

\subsubsection{S-wave velocity model and iteration curve of well 3}

The S-wave velocity model shows secondary wave velocity variation with depth (Fig. 13). Up to about $3.0 \mathrm{~m}$, the velocity increases gradually and it is observed to be constant from $3.0 \mathrm{~m}$ to $5.9 \mathrm{~m}$ from which it then begins to decrease to about $6.7 \mathrm{~m}$ from which the $\mathrm{S}$-wave velocity increases again to $13 \mathrm{~m}$. The decrease in $\mathrm{S}$ wave velocity between $3.0 \mathrm{~m}$ and $9.0 \mathrm{~m}$ is due to the presence of little clay materials within the sand unit. At these particular depths, it is observed that there is a corresponding decrease in shear modulus. At these particular depths, there is a decrease in bearing capacity and subsequently, ultimate bearing capacity.

\subsubsection{S-wave velocity model and iteration curve of well 4}

The $S$-wave velocity model shows secondary wave velocity variation with depth (Fig. 15). In this model, velocity is increases gradually and peaks at $5.3 \mathrm{~m}$; it then gradually decreases to about 12.5 $\mathrm{m}$ from which the $\mathrm{S}$-wave velocity increases again. The decrease in $\mathrm{S}$-wave velocity

Between $5.3 \mathrm{~m}$ and $12.5 \mathrm{~m}$ is due to the presence of little clay materials within the sand unit. At these particular depths, there is a corresponding decrease in shear modulus and in bearing capacity and subsequently, ultimate bearing capacity.

\subsubsection{S-wave velocity model and iteration curve of well 5}

The S-wave velocity model shows secondary wave velocity variation with depth (Fig. 17). At $0.2 \mathrm{~m}$, velocity increases

And decreases immediately, it then increases to $1.1 \mathrm{~m}$. From $1.1 \mathrm{~m}$ to $2.6 \mathrm{~m}$, velocity decreases gradually from which the S-wave velocity increases again to $6 \mathrm{~m}$. The decrease in S-wave velocity between $1.1 \mathrm{~m}$ and $2.6 \mathrm{~m}$ is due to the presence of little clay materials within the sand unit. At these particular depths, there is a 
corresponding decrease in shear modulus and in bearing capacity and subsequently, ultimate bearing capacity.

\subsubsection{S-wave velocity model and iteration curve of well 6}

The S-wave velocity model shows secondary wave velocity variation with depth (Fig. 19). Up to about $4.2 \mathrm{~m}$, the velocity increases gradually and then it begins to reduce to about $14.2 \mathrm{~m}$ from which the $\mathrm{S}$-wave velocity increases again. The decrease in S-wave velocity between $4.2 \mathrm{~m}$ and $14.2 \mathrm{~m}$ is due to the presence of little clay materials within the sand unit. At these particular depths, there is a corresponding decrease in shear modulus and in bearing capacity and subsequently, ultimate bearing capacity.

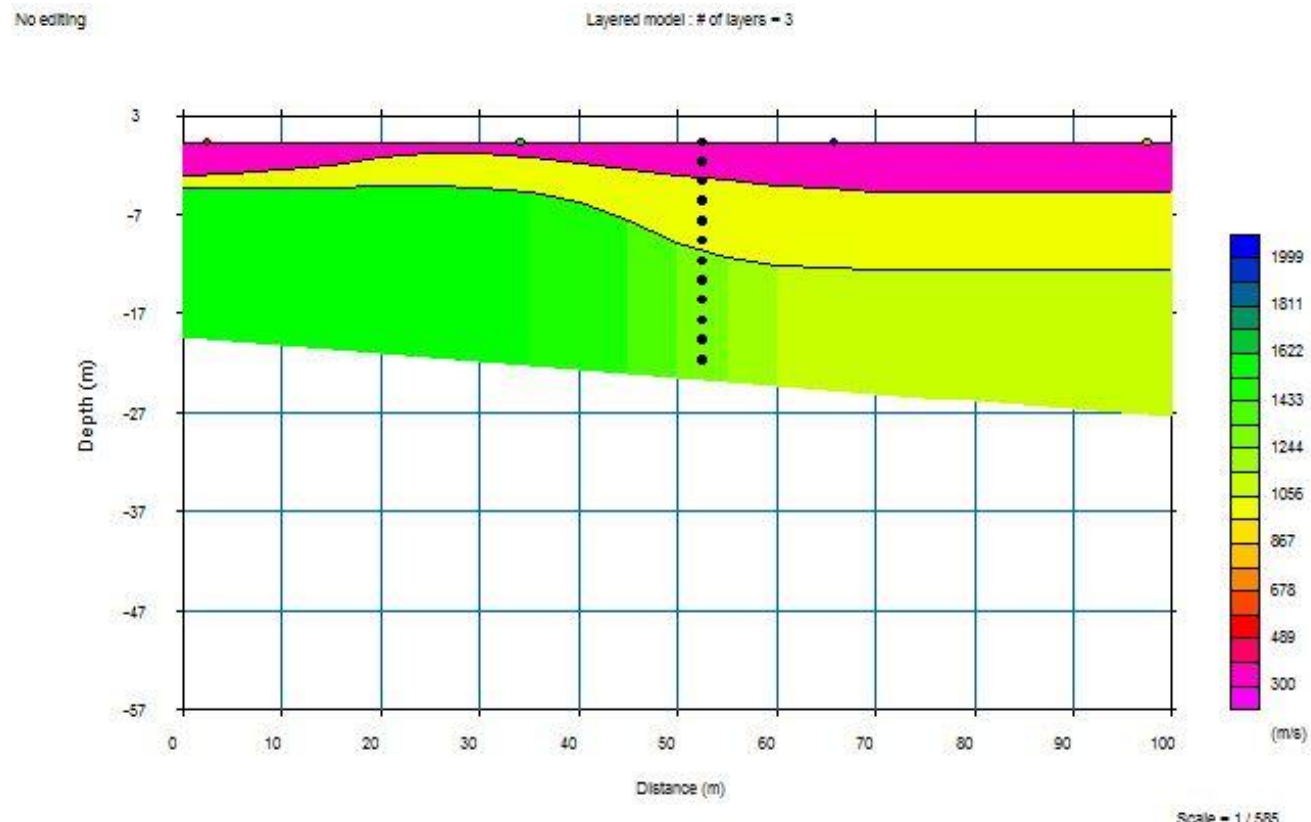

Fig. 8: Geologic Model of Well 6.

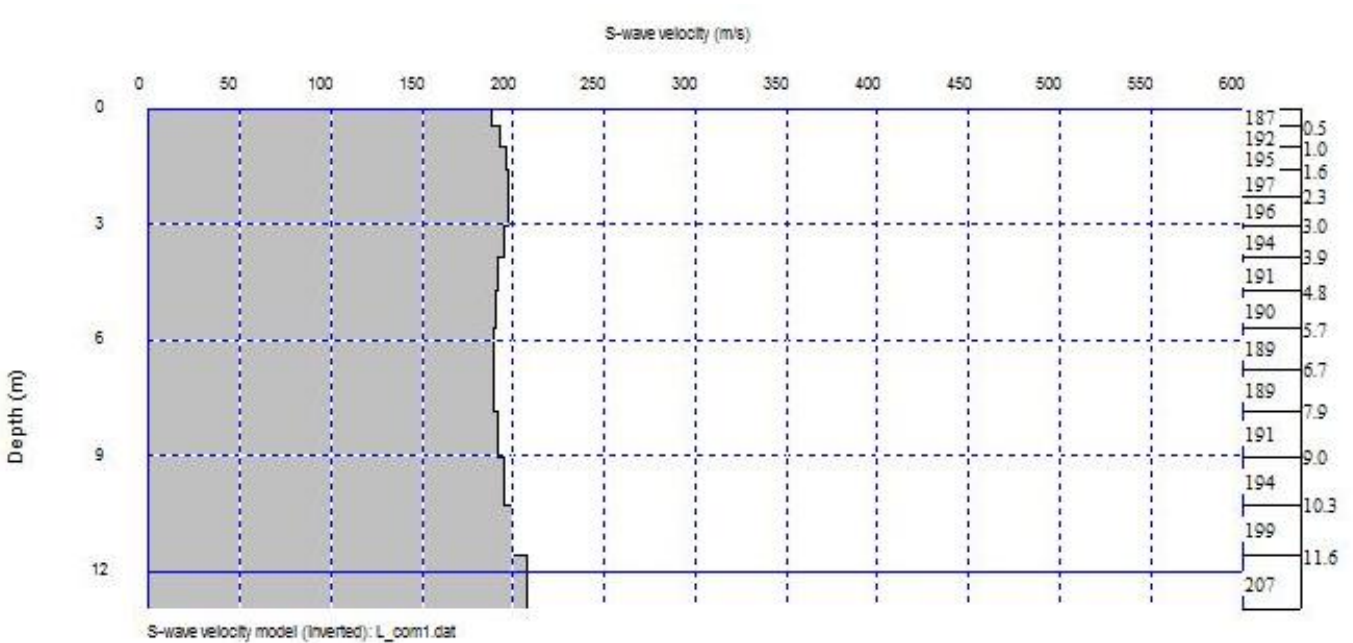

Fig. 9: S-Wave Velocity Model of Well 1.

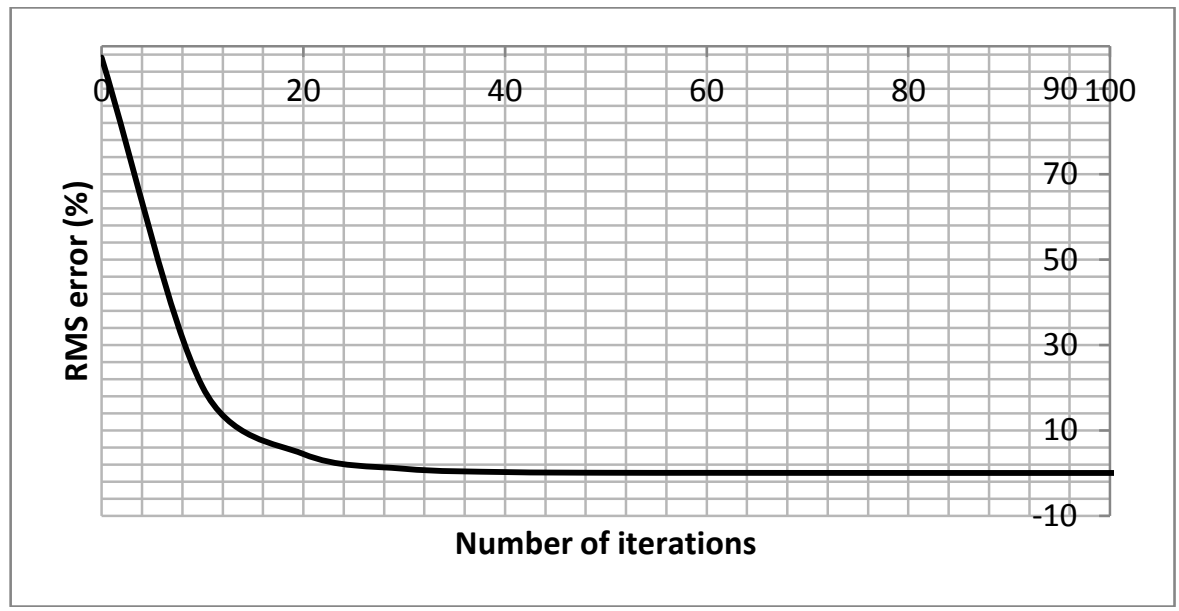

Fig. 10: Iteration Curve of Well 1. 


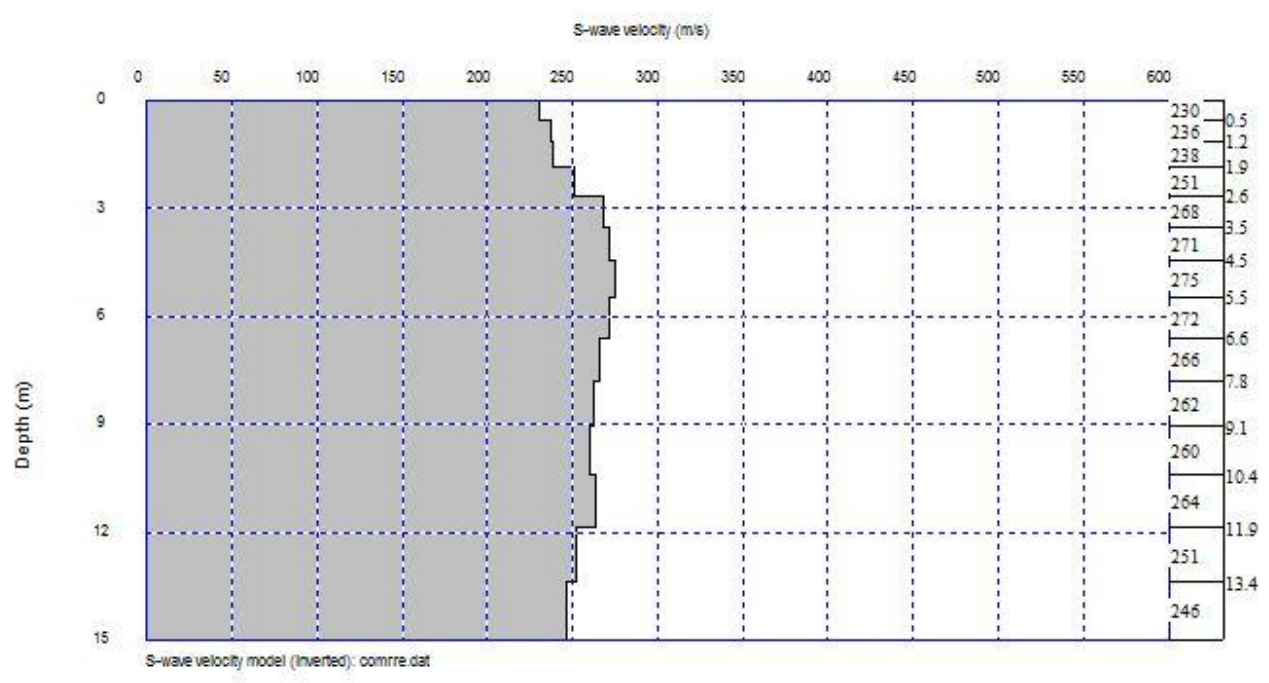

Fig. 11: S-Wave Velocity Model of Well 2.

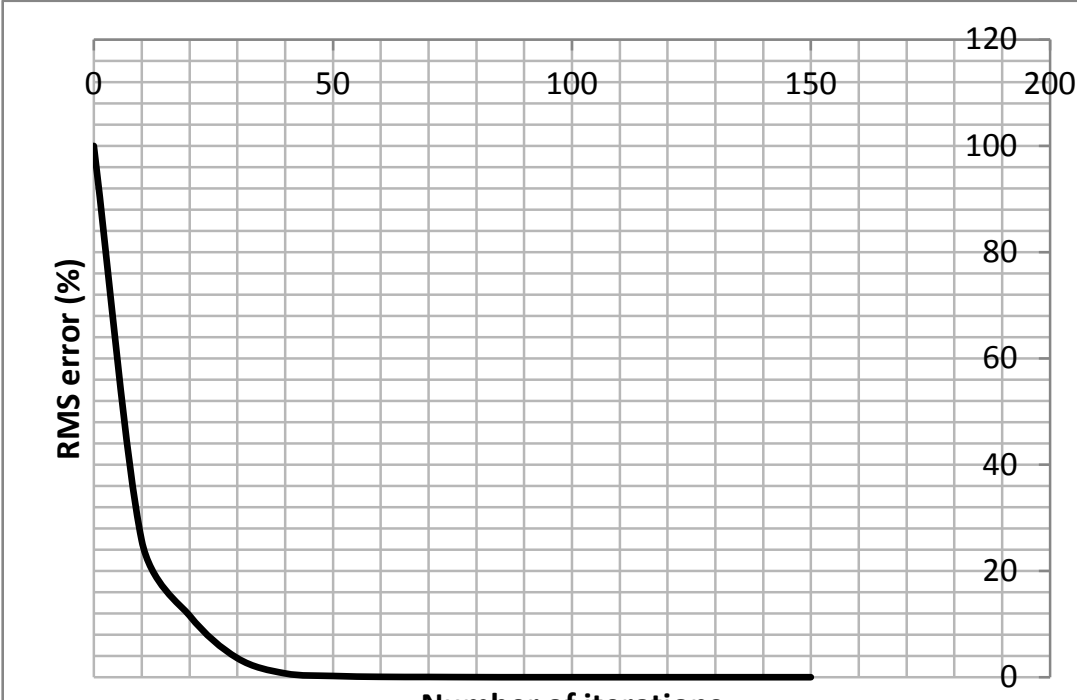

Number of iterations

Fig. 12: Iteration Curve of Well 2.

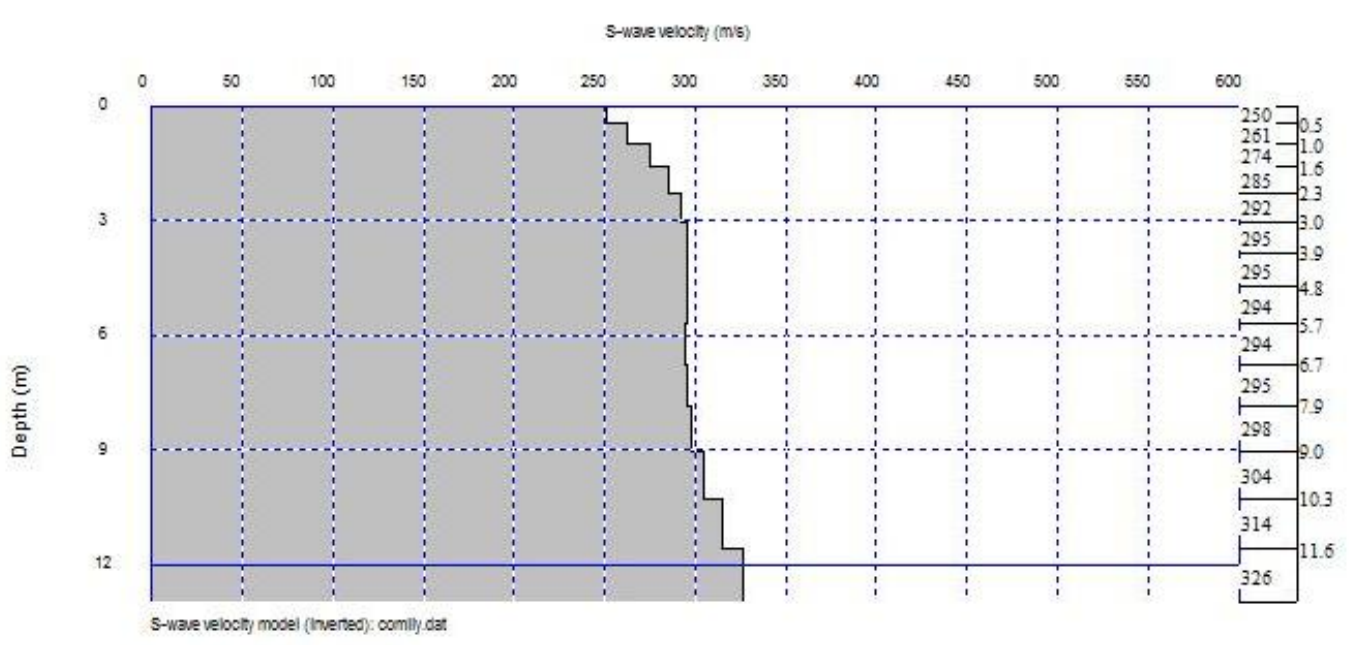

Fig. 13: S-Wave Velocity Model of Well 3. 


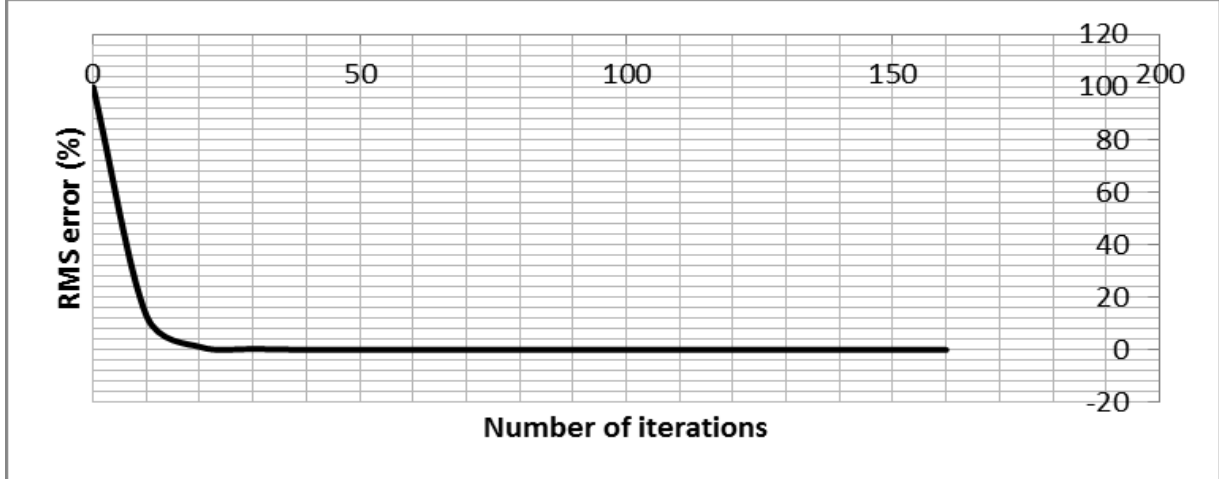

Fig. 14: Iteration Curve of Well 3.

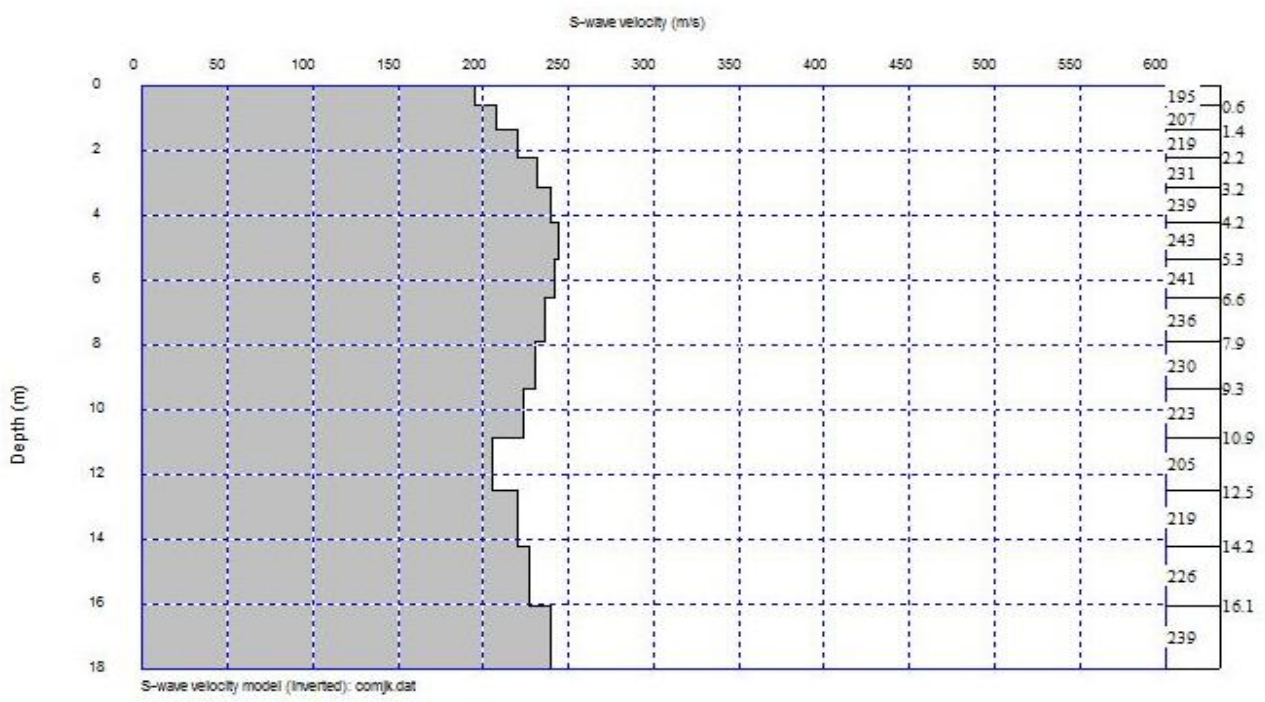

Fig. 15: S-Wave Velocity Model of Well 4.

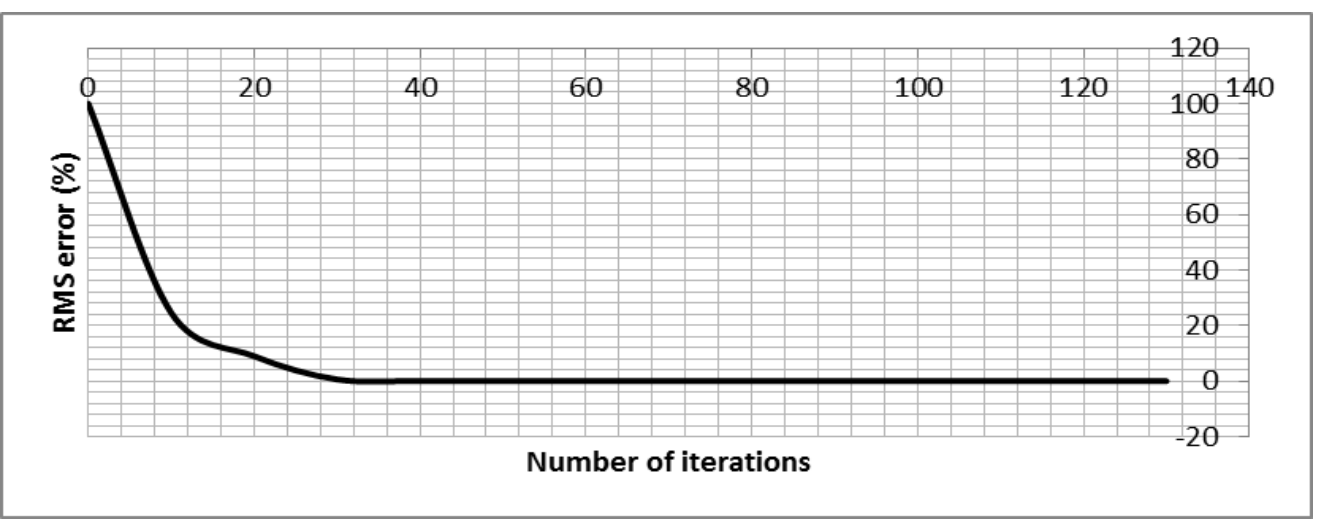

Fig. 16: Iteration Curve of Well 4.

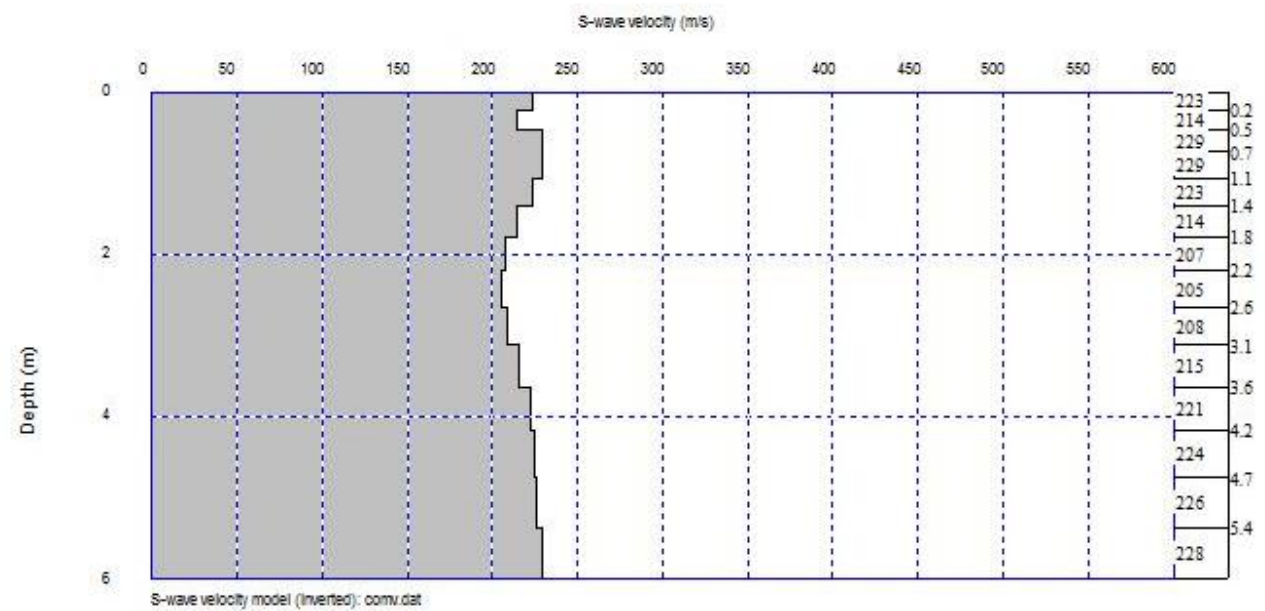

Fig. 17: S-Wave Velocity Model of Well 5. 


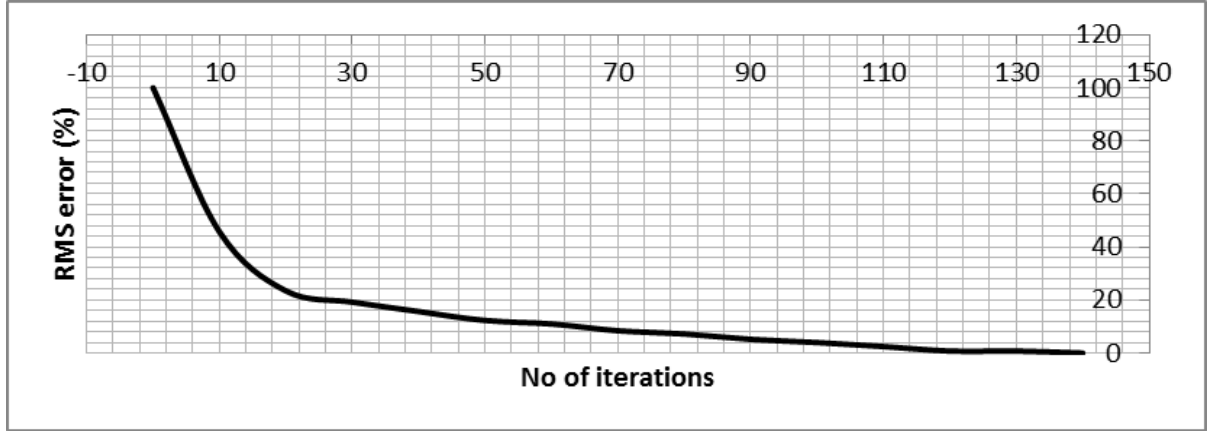

Fig. 18: Iteration Curve of Well 5.

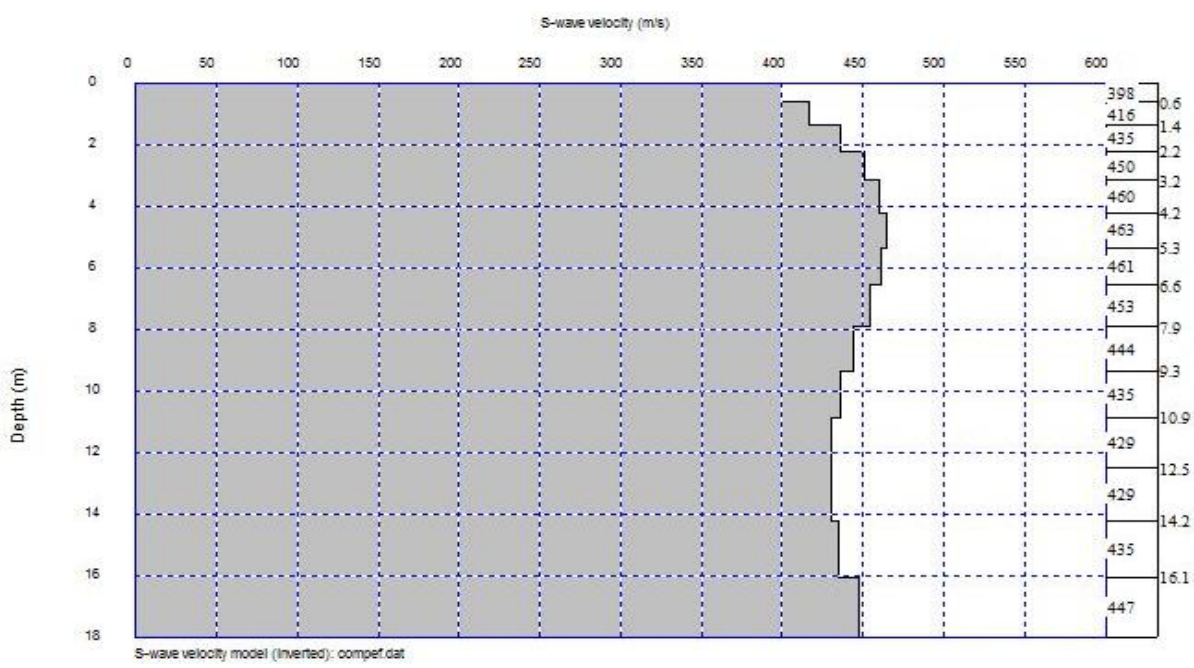

Fig. 19: S-Wave Velocity Model of Well 6.

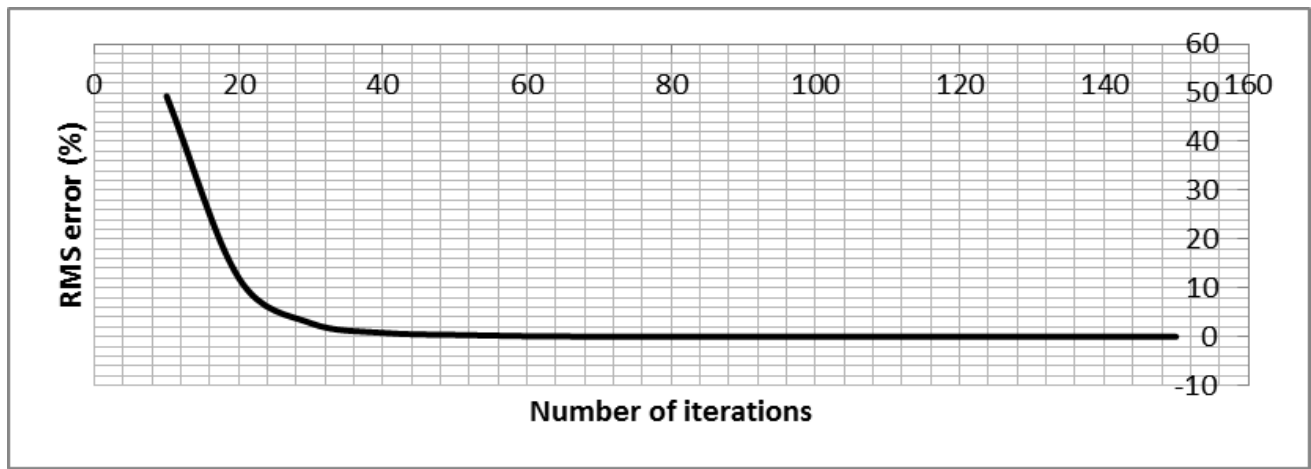

Fig. 20: Iteration Curve of Well 6.

\subsection{Empirical relations}

In other to derive the empirical relations for the investigated area from the data, the values of various elastic parameters calculated were plotted against one another. (VS - VP and $\sigma$ - VS, Figs. 21 and 23 respectively). Empirical relations derived from them represent the characteristics of the study area, Escravos, Niger Delta.

\subsubsection{VP - VS relations}

When Vp is plotted against Vs, they follow a remarkably narrow trend. Variations in porosity, caly and pressure simply move the points up and down the trend (Gary Mavko 2009). From the equation in Fig. 21, the line of best fit defines the empirical relations as:

$\mathrm{Vs}=0.902 \mathrm{Vp}-1164$.

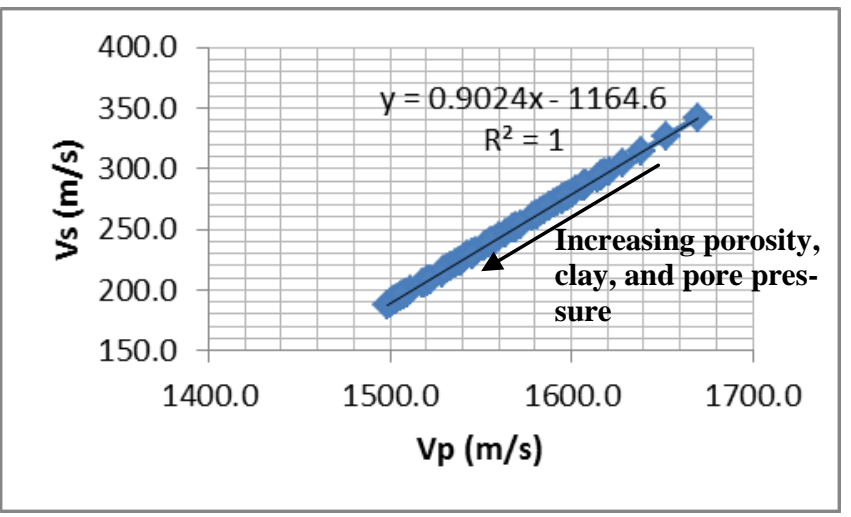

Fig. 21: Vs versus Vp.

The equation represents the empirical relation between Vs and Vp in the study area at Escravos. 


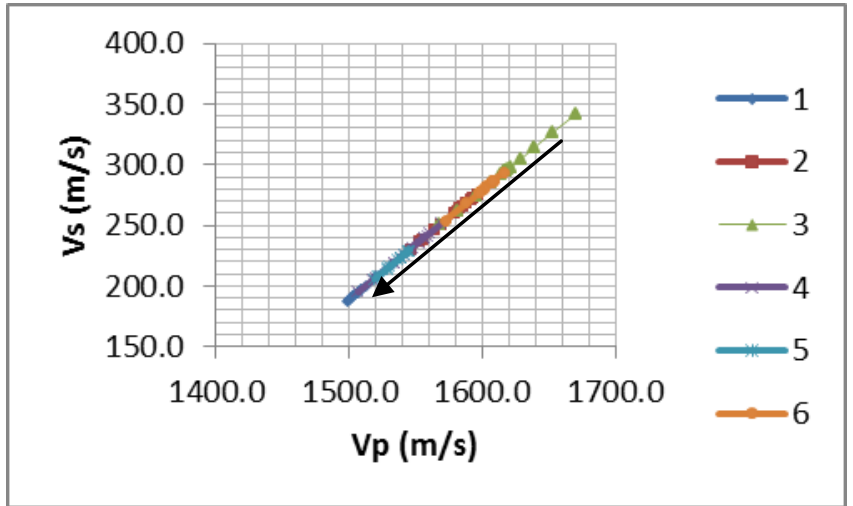

Fig. 22: Vs versus Vp of Individual Wells on the Same Graph

The arrow showing increase in porosity, clay and pore pressure also shows from Fig. 22 that porosity, clay, and pore pressure is lowest at Well 3 and increases as we move to Well 6 and is highest at Well 1.

\subsubsection{VS - poisson's ratio relations}

From this study, it is observed that a plot of $\mathrm{Vp} / \mathrm{Vs}$ versus $\mathrm{Vs}$ is inversely proportional to a plot of $\mathrm{Vp} / \mathrm{Vs}$ versus Poisson's ratio. That is:

$\frac{\mathrm{Vp} / \mathrm{Vs}}{\mathrm{Vs}}=\frac{1}{\frac{\mathrm{Vp}}{\mathrm{Vs}} /_{\text {Poisson's ratio }}}$

Which becomes:

$\frac{\mathrm{Vp} / \mathrm{Vs}}{\mathrm{Vs}}=\frac{\text { Poisson's ratio }}{\mathrm{Vp} / \mathrm{Vs}}$

$=\frac{\text { Poisson's ratio }}{\text { Vs }}$

Therefore, an attempt was made to plot Poisson's ratio against Vs.

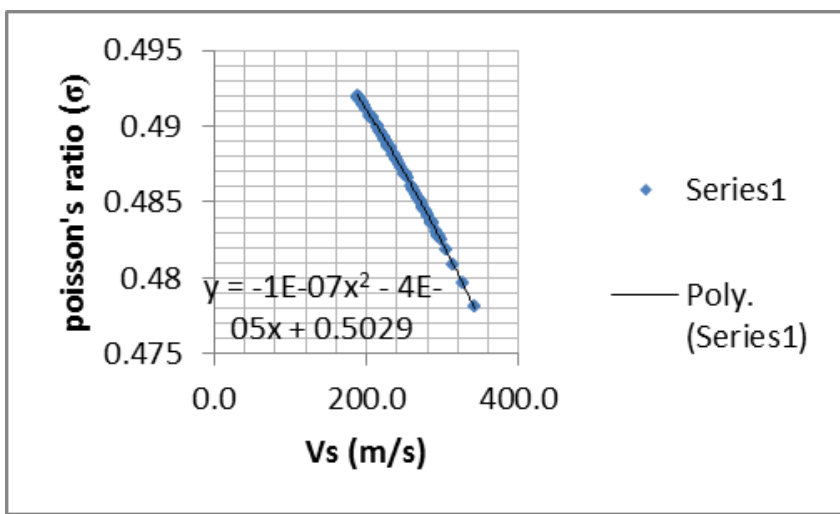

Fig. 23: Poisson's Ratio Versus Vs

The equation becomes $\sigma=-1 \mathrm{E}-07 \mathrm{Vs}^{2}-4 \mathrm{E}-05 \mathrm{Vs}+0.502$. The equation shows the empirical relations between Poison's ratio and Vs.

\section{Conclusion}

This study has shown the relevance of borehole seismic Geophysical investigation in the characterization of the subsurface geology prior to civil engineering construction. The importance of seismic velocities in providing valuable information about the bulk physical properties of rocks was also established. This type of information can be invaluable during the design and construction phases of engineering projects. Empirical relations established for Vp Vs and Vs - Poisson's is characteristics of sedimentary terrain, and can be used in any study area within the Escravos area, Niger Delta, Nigeria. The computed values of the elastic properties show that the formation encountered in the wells are moderately dense and saturated with water. This is in conformity with the fact that the major formations encountered in the wells are the Benin Formation. The Benin Formation consists of predominantly massive, highly porous, freshwater-bearing sandstones, with local thin shale interbeds. The values of allowable bearing capacity and the settlement suggest that the area of study is able to support engineering construction.

\section{References}

[1] Dobrin MB \& Savit CH (1988) Introduction to geophysical prospecting, 4th edn. McGraw-Hill.

[2] Ekweozor CM \& Daukoru EM (1994) Northern delta depobelt portion of the Akata- Agbada. (1) Petroleum system, Niger Delta, Nigeria, In, Magom, LB and Dow WG eds. The petroleum system- from source to Trap. Association of American Petroleum Geologists Memoir 60: Tulsa, $599-614$

[3] Emujakporue GO \& Ekine AS (2009) Determination of rocks elastic constants from compressional and shear waves velocities for Western Niger Delta, Nigeria: Journal of Applied Sciences and Environmental Management Vol. 13(3) 53 - 55.

[4] Gary Mavko (2009) Stanford Rock Physics Laboratory. The rock physics of AVO.

[5] Hardage BA (1985) Vertical Seismic Profiling- part A: Principles, Geophysical Press, London.

[6] Hardage BA (1989) Vertical Seismic Profiling in hydrocarbon exploration and reservoir development. Philips Petroleum Company, Bartlesville, Oklahoma, USA. Circum-Pacific Council for Energy and Mineral Resources 2009 - Petroleum Resources of China and Related Subjects, Vol. 10, 1989.

[7] Hardin BO \& Black WL (1968) Vibration modulus of normally consolidated clays, Journal of the Soil Mechanics and Foundation Division, ASCE, Vol.94, No.SM2, pp. 353 - 369.

[8] Imai T \& Yoshimura M (1972) the relation of mechanical properties of soils to P and $\mathrm{S}$ wave velocities for soil ground in Japan. Urana Research Institute, OYO Corp.

[9] Imai S (1975) an investigation to geophysical prospecting for civil purposes OYO Co-operation, Tokyo, Japan.

[10] Keçeli AD (1990) the determination of the bearing capacity by means of the seismic method: Jeofizik 4, 83 92. (In Turkish).

[11] Keceli AD (2000) the determination of the presumptive bearing capacity by means of the seismic method: JEOFIZIK, Cilt: 14, Say1: 1 2. (In Turkish).

[12] Keceli AD (2012) Soil parameters that can be determined with seismic velocities. Jeofizik, 2012.

[13]Michele LWT, Ronald RC \& Michael E (1999) The Niger delta petroleum system: Niger delta province, Nigeria, Cameroon, and Equatorial Guinea, Africa. Open file report 99 50-H.

[14]Ohkubo T \& Terasaki A (1976) Physical property and seismic wave velocity of rocks, OYO Corporation, Japan.

[15]Parry RHG (1977) Estimating bearing capacity of sand from SPT values Journal of Global Environment Engineering, ASCE 103:Gt.9 pp.1014 - 1043 .

[16]Sheriff RE (1989) Geophysical methods. Prentice Hall, New Jersey. 1st Edition.

[17] Sternberg BK, Poulton MM \& Thomas SJ (1990) Geophysical investigations in support of the Arizona SSC project. (In Geotechnical and Enviromental Geophysics, S.E.G. V.III:211 228).

[18]Uko ED (1996) Thermal modeling of the Northern Niger delta. Un published Ph.D. Thesis, Rivers State University of Science and Technology, Port Harcourt. 